\title{
Dipyridamole potentiated the trypanocidal effect of nifurtimox and improved the cardiac function in NMRI mice with acute chagasic myocarditis
}

\author{
Sonia Santeliz', Peter Caicedo², Elidiosmar Giraldo², Carmen Alvarez¹, María-Daniela Yustiz², \\ Claudina Rodríguez-Bonfante ${ }^{3}$, Romina Bonfante-Rodríguez ${ }^{2}$, Rafael Bonfante-Cabarcas ${ }^{2}{ }^{+}$
}

\author{
'Decanato de Ciencias Veterinarias, Unidad de Biomedicina, Departamento de Medicina y Cirugía, Barquisimeto, Estado Lara, Venezuela \\ ${ }^{2}$ Decanato de Ciencias de la Salud, Unidad de Bioquímica, Barquisimeto, Estado Lara, Venezuela \\ ${ }^{3}$ Universidad Centroccidental Lisandro Alvarado, Unidad de Parasitología Médica, Barquisimeto, Lara, Venezuela
}

BACKGROUND As chronic Chagas disease does not have a definitive treatment, the development of alternative therapeutic protocols is a priority. Dipyridamole (DPY) is an alternative to counteract the pathophysiological phenomena involved in Chagas cardiomyopathy.

OBJECTIVE To evaluate the therapeutic efficacy of DPY associated with nifurtimox ( $\mathrm{Nfx}$ ) in epimastigote axenic cultures and in mice with acute Chagas disease.

METHODS NMRI adult male mice were divided into nine groups: three healthy and six Trypanosoma cruzi-infected groups. Mice received vehicle, Nfx or DPY, alone or combined. The doses assayed were Nfx 10 and $40 \mathrm{mg} / \mathrm{kg}$ and DPY $30 \mathrm{mg} / \mathrm{kg}$. The treatment efficacy was evaluated by clinical, electrocardiographic, parasitological, biochemical and histopathological methods.

FINDINGS In vitro, DPY and Nfx had a trypanocidal effect with $\mathrm{IC}_{50}$ values of $372 \pm 52$ and $21.53 \pm 2.13 \mu \mathrm{M}$, respectively; DPY potentiated the Nfx effect. In vivo, Nfx $(40 \mathrm{mg} / \mathrm{kg})$ with or without DPY had a therapeutic effect, which was reflected in the $84-$ $92 \%$ survival rate and elimination of parasitaemia and heart tissue amastigotes. Nfx $(10 \mathrm{mg} / \mathrm{kg})$ had a subtherapeutic effect with no survival and persistence of amastigotes, inflammation and fibrosis in heart tissue; adding DPY increased the survival rate to $85 \%$, and all tested parameters were significantly improved.

MAIN CONCLUSION DPY has a trypanocidal effect in vitro and enhances the Nfx therapeutic effect in an in vivo murine model.

Key words: Chagas disease - nifurtimox - dipyridamole - Trypanosoma cruzi - treatment

In the last two decades, sufficient data have been generated to suggest that Chagas disease is a global public health problem. Approximately 6 million to 7 million people worldwide, mostly in Latin America, are estimated to be infected with Trypanosoma cruzi, the parasite that causes Chagas disease, which is found mainly in endemic areas of 21 Latin American countries, where it is estimated that there is a population of 70,199,360 individuals at risk of acquiring the infection; 5,742,167 infected people; and 29,925 new cases per year with a mortality of 12,000 individuals per year (Dias et al. 2016, WHO 2017). Active vector transmission remains, which is reflected in the onset of acute Chagas disease cases in regions infested by vectors (Añez et al. 2004), and there is re-emergence of the disease manifested by the appearance of circumscribed outbreaks by oral transmission (Alarcón de Noya et al. 2015). The migration of infected people from underdeveloped South American countries to developed countries has enabled

doi: 10.1590/0074-02760160499

Financial support: National Fund for Science and Technology (FONACIT) under the Ministry of Popular Power for Science and Technology (Venezuela) (Project No 2007001425) and by CDCHT at Universidad Centroccidental Lisandro Alvarado (Venezuela) (Doctoral project number 001-DVE-2014).

+Corresponding author: rbonfantecabarcas@gmail.com

Received 15 November 2016

Accepted 22 April 2017 disease globalization, reporting a prevalence of $4.2 \%$ in these immigrant Latin-American populations in those countries (Requena-Méndez et al. 2015).

Although Chagas disease vector transmission has been controlled in most endemic areas of Latin America with a drastic decrease in new cases, Chagas disease still has a high residual prevalence in areas such as Bolivia (Medrano-Mercado et al. 2008), and a high incidence of acute cases is present in specific areas (Añez et al. 2004, Alarcón de Noya et al. 2015). As parasitic treatment in chronic cases remains controversial due to a lack of clinical efficacy of the current trypanocidal drugs, the development of new therapeutic schemes is welcome. Nifurtimox (Nfx) and benznidazole (BZL) are classic drugs accepted for Chagas disease treatment, and both act through free radical generation. There is consensus that both drugs are effective for treating Chagas disease in its acute phase, while their therapeutic effect in the chronic phase is rather limited (Murcia et al. 2012). When performing a critical review of the literature data, the findings are controversial; it has been found that parasitological cures do not run parallel with the decrease in the serum anti-T. cruzi antibodies (Sguassero et al. 2015), indicating the persistence of a latent infection. What has been consistently reported is that treatment with Nfx and BZL decreases the parasite load, delaying or preventing the development of chronic chagasic cardiomyopathy (Coura \& Borges-Pereira 2011), but there 
is no guarantee that a parasitological "cure" in chronic Chagas disease patients translates into a change in the clinical prognosis of the patient, especially when serological titres remain positive. Side effects depend on the generation of free radicals, and reactive oxygen species described for both drugs are an important issue, which causes demotivation in doctors who lack expertise in the use of both drugs. However, side effects are no longer a reason not to treat (Murcia et al. 2012).

An alternative view to developing new therapeutic drugs is the use of protocols in which the classical drugs Nfx and BZL are combined with potentially useful drugs, from the parasitological and pathophysiological point of view. The drugs to be tested should ideally have a trypanocidal effect or enhance the trypanocidal effect of Nfx or BZL, counteract the side effects of both drugs, stimulate the immune system, have an anti-inflammatory effect, and improve cardiac function; also, there must be sufficient experience in the therapeutic use of the drug in humans.

Dipyridamole (DPY) is an old drug whose mechanism of action seems to indicate that it meets the aforementioned characteristics. It has been used primarily as a platelet aggregation inhibitor in preventing cerebral thromboembolic diseases. Its mechanism of action is based on inducing elevated levels of extracellular adenosine and by inhibiting the phosphodiesterase five (PDE5) enzyme. Adenosine has cardioprotective effects by decreasing the metabolic rate due to its chronotropic, inotropic and dromotropic negative effects, and it causes coronary vasodilation, improving the coronary flow and preventing platelet aggregation, which reduces the chances of platelet thrombi development (Layland et al. 2014). Additionally, adenosine is an autacoid anti-inflammatory hormone with immunoregulatory properties that can limit the damage induced by inflammation and hypoxia (Palmer \& Trevethick 2008). Furthermore, the molecular structure of DPY allows it to accept electrons, working as a free radical scavenger and antioxidant agent (Kim \& Liao 2008).

Parasite persistence and immune-mediated cardiac damage are considered the main mechanism for Chagas disease progression. However, an interesting point in the pathophysiology of Chagas cardiomyopathy involves microvasculature disorders with increased platelet aggregation, resulting in vasospasm and thrombus formation and causing ischaemia and necrosis, which progressively leads to cardiac remodelling and chronic cardiomyopathy (Rossi et al. 2010). In addition, intense inflammation and free radical generation are key factors in the residual damage caused by T. cruzi (Vyatkina et al. 2004).

There is a need for new drugs because of a lack of efficacy of the current trypanocidal drugs to change the natural history of chronic Chagas disease cases. Therefore, given the pharmacological and therapeutic characteristics of DPY, it could help treat Chagas disease as an adjuvant drug by acting as a cardioprotective drug that should counteract some pathophysiological phenomena induced by infection and side effects induced by Nfx, decreasing the disease sequelae.

In the present paper, we study the therapeutic effect of DPY $(30 \mathrm{mg} / \mathrm{kg}$ ) combined with $\mathrm{Nfx}(10$ or $40 \mathrm{mg} /$ $\mathrm{kg}$ ) in NMRI male mice with acute chagasic myocarditis that were treated from the third week post-infection.

\section{MATERIALS AND METHODS}

T. cruzi axenic cultures - The strain of T. cruzi used in this work was M/HOM/VE/92/2-92-YBM. The strain has been maintained through successive passages from the vector to a susceptible host. The vectors were Rhodnius prolixus stage III nymphs, and NMRI mice were used as a susceptible host. Drug inhibitory effects were tested at concentrations between $1 \mu \mathrm{M}$ and $1 \mathrm{mM}$ in a final volume of $10 \mathrm{~mL}$ of liver infusion tryptose (LIT) medium in $50-\mathrm{mL}$ Falcon tubes in triplicate. Parasitic proliferation began with an OD of $0.2\left(4 \times 10^{6}\right.$ parasites $\left./ \mathrm{mL}\right)$ when parasites were in a logarithmic phase of growth. Epimastigotes were cultured under continuous stirring in a rotary incubator at $28^{\circ} \mathrm{C}$ for 48 to $72 \mathrm{~h}$.

In vivo model - Animals used in this study were NMRI albino mice, adult males, 30-40 g weight, from the animal facilities of Universidad Centroccidental Lisandro Alvarado, Venezuela. Mice were kept in $40 \mathrm{x}$ $25 \times 15 \mathrm{~cm}$ stainless steel cages, with 5-10 animals per cage, at a temperature between $25-30^{\circ} \mathrm{C}, 12$-h light/darkness cycles and relative humidity of $65 \%$. Feeding was based on concentrated feed (Perrarina ${ }^{\circledR}$, Protinal, Venezuela), and sterilised water was provided ad libitum.

The tested drugs were as follows. (i) Nifurtimox, Lampit ${ }^{\circledR}$ (Bayer Corporation Bonima SA, El Salvador), which was packaged in $120 \mathrm{mg}$ tablets. For in vitro experiments, tablets were pulverised in a mortar and suspended in dimethyl sulphoxide (DMSO) in a final volume (VF) of $10 \mathrm{~mL}$; they were extracted under continuous stirring for $24 \mathrm{~h}$ and then centrifuged at 2000 $\mathrm{rpm}$ for $30 \mathrm{~min}$. The supernatant with drug dissolved at a concentration of $41.77 \mathrm{mM}$ was obtained, and the drug was tested at final concentrations between 0.1-100 $\mu \mathrm{M}$. For in vivo experiments, one or four tablets were crushed and suspended in $12 \mathrm{~mL}$ of $1 \%$ carboxymethylcellulose, resulting in concentrations of 10 or $40 \mathrm{mg} / \mathrm{mL}$, respectively. The dose was 10 or $40 \mathrm{mg} / \mathrm{kg}$ weight and orally administered using a micropipette. (ii) Dipyridamole (Sigma-Aldrich) stock solution of $1 \times 10^{-2} \mathrm{M}$ in absolute ethanol was prepared for in vitro experiments, and the drug was tested at concentrations between 0.01-1 mM. For in vivo experiments, suspensions of $30 \mathrm{mg} / \mathrm{mL}$ were prepared in $1 \%$ carboxymethylcellulose, and the administered dose was $30 \mathrm{mg} / \mathrm{kg}$ weight, which was orally administered with a micropipette.

The therapeutic protocol consisted of nine groups of 20 NMRI adult male mice each, including three groups of healthy mice receiving vehicle, $\mathrm{Nfx} 40 \mathrm{mg} / \mathrm{kg}$ or DPY 30 $\mathrm{mg} / \mathrm{kg}$ and six groups of $T$. cruzi-infected mice treated with vehicle, Nfx 10 or $40 \mathrm{mg} / \mathrm{kg}$, DPY $30 \mathrm{mg} / \mathrm{kg}$, Nfx $10 \mathrm{mg} / \mathrm{kg}$ plus DPY $30 \mathrm{mg} / \mathrm{kg}$ and Nfx $40 \mathrm{mg} / \mathrm{kg}$ plus DPY $30 \mathrm{mg} / \mathrm{kg}$.

Infected mice were orally treated daily with selected drugs until the parasitaemia was demonstrated as negative for three consecutive weeks of observation. Then, monthly parasitaemia monitoring was performed, and treatment was resumed in mice with reactivation of parasitaemia. Treatment protocols were performed for a maximum period of 6 months. Additionally, experiments were interrupted if the group mortality reached $50 \%$. 
Electrocardiographic (ECG) studies - These studies were conducted at the end of the treatment protocol. Under general anaesthesia with pentobarbital $50 \mathrm{mg} / \mathrm{kg}$ and xylazine $1 \mathrm{mg} / \mathrm{kg}$ ip, mice were placed in the supine position and electrodes were placed into the subcutaneous tissue. We worked with four ECG leads: DI, DII, DIII and AVF. Recording was performed in a bipolar configuration, and analogue signal was amplified with a bioamplifier (BIO Amp - ADInstruments) and transformed into a digital signal by an interface Power Lab/8sp (ADInstruments, USA). The signal generated was filtered at $60 \mathrm{~Hz}$ and captured at $10 \mathrm{kHz}$. The electrocardiographic signal was displayed during the experiment, stored and analysed using the LabChart program.

Behavioural assessment - Since it has been reported that the most serious side effects resulting from the administration of $\mathrm{Nfx}$ are peripheral neuropathies and central nervous system disorders of the higher functions, we decided to evaluate nociception by the hot plate and formalin tests, while motor function was evaluated by assessing motility on an open field.

The hot plate test consisted of individually placing each mouse in a box with dimensions of $32 \times 32 \times 26 \mathrm{~cm}$. The walls were constructed of transparent acrylic and thermally conductive granite floor. On the pre-trial day, the animal was placed in the behavioural box for $10 \mathrm{~min}$ with the floor at room temperature. On the trial day, the animal was placed in the behavioural box with the conductive floor at $40^{\circ} \mathrm{C}$ and the latency time it takes the mouse to lick his hind legs is measured up to a maximum of $5 \mathrm{~min}$.

The formalin test consisted of injecting $50 \mu \mathrm{L}$ of $5 \%$ formalin into the subcutaneous tissue in the dorsal surface of the paw. Then, each mouse was individually placed in a glass cylinder with a diameter of $30 \mathrm{~cm}$ and height of 30 $\mathrm{cm}$ at room temperature; the number of licking events in the injected paw was quantified in 5-min periods for a total of $30 \mathrm{~min}$. The experiment requires a prior conditioning period a day before the measurement, placing the ani$\mathrm{mal}$ in the glass cylinder for $10 \mathrm{~min}$ at room temperature.

Biochemical tests - Creatine kinase MB (CKMB) and glutamic oxaloacetic transaminase (SGOT) plasma levels were determined using commercial kits according to the manufacturer's instructions. Blood samples were taken by cardiac puncture using heparinised syringes. Samples were centrifuged at $2500 \mathrm{rpm}$ for $5 \mathrm{~min}$, and plasma was aspirated and stored in small aliquots at $-70^{\circ} \mathrm{C}$ until their use.

Histopathological studies - Mice were euthanised by exsanguination with cardiac puncture under general anaesthesia. Autopsy was performed, and heart tissue samples were fixed in 10\% formalin in PBS, embedded in paraffin, cut into 200-micron slices and stained with haematoxylin-eosin or Masson trichrome.

Data analysis - The obtained data were expressed in absolute, percentage or average values \pm standard deviation (SD; for tables) or standard error (SEM; for figures). Normality was determined with the D'Agostino Pearson omnibuss normality test. The analysis of the observed difference between two groups was performed using Student's t test and that between more than three groups was performed using ANOVA followed by Bonferroni's post-test. In all cases, a value of $p<0.05$ was accepted as significant.

To get an $\mathrm{IC}_{50}$, the results obtained in the inhibition curves were analysed by nonlinear regression using the inhibition dose-response curves type based on a sigmoid equation. All analyses were performed using GraphPad Prism (San Diego, CA).

For ECG analysis, 54 healthy mice and 111 mice with acute Chagas ECG traces were included. These mice belong to the database of our laboratory raised from other studies; these mice were handled similarly as mice from the experimental protocol. ECG analysis was systematised to detect rhythm, conduction and repolarisation disorders. For quantitative disorders, we based the values of the 10th and 90th percentiles (p10 and p90) of the ECG parameters calculated in the healthy mice, accepting abnormal values as those below and above these percentiles. Also, the ECG traces were tracked for morphologic qualitative disturbances.

For rhythm disorders, we defined bradycardia and tachycardia based on lower than p10 and higher than p90 values of the heart rate, respectively. Extrasystole was defined as a premature QRS complex followed by a compensatory pause. The origins of the quantitative disorders and extrasystoles were classified as follows: sinus when the QRS complex was preceded by a P wave, nodal when there was not a P wave and the QRS complex morphology was similar to the basal traces, and ventricular when there was no P wave and the QRS morphology was different from the basal traces. Atrial fibrillation was defined based on the absence of a $\mathrm{P}$ wave or atrioventricular dissociation, and both had variable RR intervals.

Conduction disorders were defined as lengthening of the PR segment or QRS complex, and the period's durations were corrected by the Bazett method. Sinoatrial conduction disorders were classified in I, II and III degree blockages. Those of I degree involved PR lengthening with values greater than p90 of healthy animals. Degree II was defined when PR intervals remain constant; however, sometimes there was no QRS complex following P waves. Degree III blockage (atrioventricular dissociation) was defined as $\mathrm{P}$ waves not synchronised with QRS complexes with different PP and RR interval values, while intraventricular conduction disorders were defined based on the p10 and p90 QRS complex duration.

Repolarisation disorders were defined as $\mathrm{T}$ wave disorders with the $\mathrm{T}$ wave being the positive deflection following the S wave above the isoelectric line. Quantitative $\mathrm{T}$ wave disorders were defined by the $\mathrm{T}$ wave amplitude and QT intervals (which start at the Q wave of the QRS complex and end when the T wave returns to the isoelectric line) taking p90 and p10 into account. The $\mathrm{T}$ wave decrease was analysed by means of an exponential decay equation with two components, defining the values of the $t_{1}$ and $t_{2}$ constants with their respective percentage in the amplitude of the decay. Qualitative disorders were visualised as flattening or inversion of the $T$ wave or as post-depolarisation visualised as a wave ( $\mathrm{U}$ wave) that emerged during the second component of the $\mathrm{T}$ wave decay. All quantitative analyses were calculated using LabChart data analysis software (ADInstruments). 
Ethics - The project was approved on January 24, 2014, by the Ethics Committee of the Health Sciences School, Universidad Centroccidental Lisandro Alvarado, Barquisimeto, Venezuela. Murine manipulation was performed according to the ethical criteria for the use of experimental animals of the National Endowment for Science Technology and Innovation (http://www.cdc. fonacit.gob.ve/boletin/libro2_311003.html).

\section{RESULTS}

$N f x$ and DPY potency in vitro - Inhibition curves performed on epimastigotes in the logarithmic phase of growth gave $\mathrm{IC}_{50}$ values of $21.53 \pm 2.13$ and $372 \pm 52$ $\mu \mathrm{M}$ for Nfx and DPY, respectively (Fig. 1A). To study the NFX/DPY interaction, we determined the effect of $20 \mu \mathrm{M}$ DPY on the inhibition induced by 5, 10 and 20 $\mu \mathrm{M}$ NFX. Fig. 1B clearly shows that DPY enhances the inhibitory effect of $\mathrm{Nfx}$ on parasite proliferation.

Parasitaemia - Parasitaemia values obtained at the end of the protocol in the Nfx-treated groups compared with the control Chagas group are shown in Fig. 2, panel A. All treated groups, including the DPY group, showed significantly lower parasitaemia compared to the Chagas control group. In panel B, the evolution of parasitaemia is displayed in relation to the time course of treatment with Nfx to $40 \mathrm{mg} / \mathrm{kg}$, alone and combined with DPY, obtaining $\mathrm{t}_{50}$ values (days needed to decrease parasitaemia by $50 \%$ ) of 6.9 and 9.3 days, respectively. In panel C, the percentages of survival are shown, demonstrating that the control Chagas, DPY and Nfx $10 \mathrm{mg} / \mathrm{kg}$ groups showed $100 \%$ mortality, while mice treated with $\mathrm{Nfx} 40 \mathrm{mg} / \mathrm{kg}$, $\mathrm{Nfx} 10 \mathrm{mg} / \mathrm{kg}$ or $40 \mathrm{mg} / \mathrm{kg}$ associated with DPY showed survival percentages of 92,84 and $85 \%$, respectively.

$E C G$ - To visualise clearly ECG changes induced by treatment, we first analysed ECG traces in 74 healthy mice and 131 infected mice in the acute phase of Chagas disease and then compared them with the traces obtained in mice belonging to the experimental groups.
A

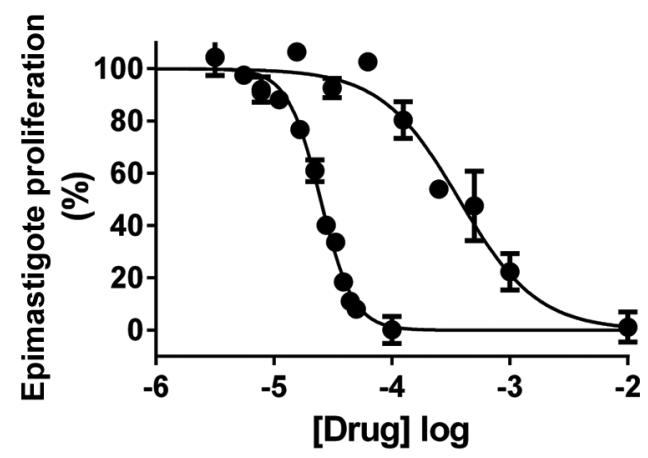

B

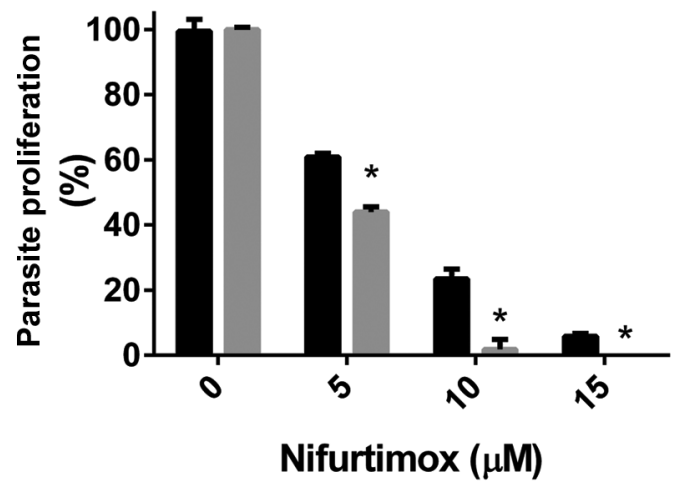

Fig. 1: effect of nifurtimox (Nfx) and dipyridamole (DPY) in epimastigote axenic culture. After epimastigote growth in liver infusion tryptose (LIT) medium at $28^{\circ} \mathrm{C}$ under continuous rotational shaking until they achieved logarithmic growth with a density of $4 \times 10^{6}$ parasites $/ \mathrm{mL}$, moment Nfx $(1$ $\mu \mathrm{M}$ to $1 \mathrm{mM})$ and/or DPY (10 $\mu \mathrm{M}$ to $1 \mathrm{mM})$ was added and then incubated for 48 h. (A) Normalised dose response curves for Nfx (left) and DPY (right); observe that Nfx had 10 times more potency than DPY on the inhibition of epimastigote proliferation. (B) DPY $(20 \mu \mathrm{M})$ was assayed at 5, 10 and $15 \mu \mathrm{M}$ doses of Nfx; observe that DPY potentiated the effect of Nfx.
A

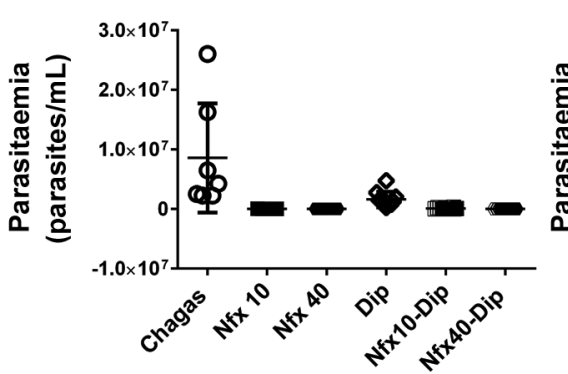

B

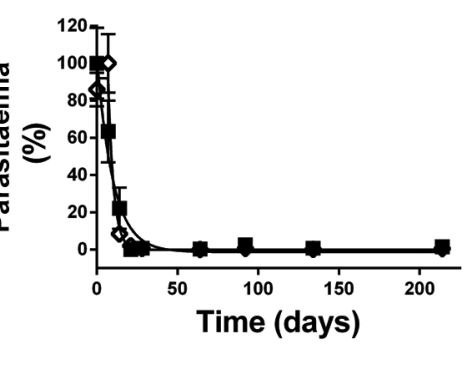

C

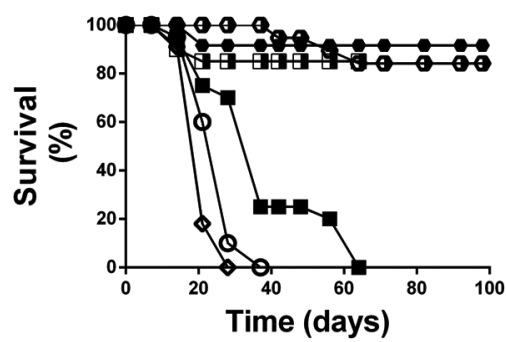

Fig. 2: parasitaemia and survival in infected mice treated with nifurtimox (Nfx) and/or dipyridamole (DPY). Parasitaemia was quantified using Newbauer's camera seeded with $5 \mu \mathrm{L}$ of blood diluted $1: 10$ in $\mathrm{NaCl} 0.9 \%$; mortality was registered until $50 \%$ of mice for the determined group died. (A) Shows parasitaemia obtained at the end of the experiment; observe that groups treated with Nfx alone or combined with DPY had parasitaemia close to 0, while parasitaemia persisted in control Chagas mice and DPY-treated mice. However, parasitaemia with DPY was significantly lower than control Chagas mice. (B) Shows parasitaemia evolution as a function of time in mice treated with $\mathrm{Nfx} 40 \mathrm{mg} / \mathrm{kg}$ (black filled squares) and Nfx $40 \mathrm{mg} / \mathrm{kg}$ plus DPY $30 \mathrm{mg} /$ $\mathrm{kg}$ (open diamond); parasitaemia achieved values close to 0 from the 25 th day, and the DPY-Nfx group tended to increase parasitaemia in the first week. (C) Shows survival curves for control Chagas (open circle), DPY $30 \mathrm{mg} / \mathrm{kg}$ (open diamond), Nfx $10 \mathrm{mg} / \mathrm{kg}$ (black filled square), Nfx $40 \mathrm{mg} / \mathrm{kg}$ (hexagon total black filled), Nfx $10 \mathrm{mg} / \mathrm{kg}$ plus DPY (square half black filled) and Nfx $40 \mathrm{mg} / \mathrm{kg}$ plus dipyridamole (hexagon half black filled) groups. The control Chagas and DPY and Nfx $10 \mathrm{mg} / \mathrm{kg}$ groups achieved $100 \%$ mortality and mortality between 10 and $20 \%$ in the reamaining groups, respectively. 
In chagasic mice, compared with healthy mice, ECG disorders in virtually all parameters were observed, except for the $\mathrm{S}$ wave amplitude, $\mathrm{P}$ wave axis, second component of the T wave decay $\left(\mathrm{t}_{2}\right)$ and in the QT interval length. Healthy mice displayed very few ECG qualitative disturbances; we only observed sinus extrasystole in $6(8.1 \%)$ individuals. By contrast, $65.4 \%$ of chagasic mice displayed some type of disturbance, which was most frequently a post-depolarisation (U) wave $(65.4 \%)$, sinus extrasystole $(23.5 \%)$, ventricular extrasystole (21.3\%), two independent $\mathrm{P}$ waves (19.8\%) and a bifid $\mathrm{P}$ wave (17.6\%). Also, we observed severe rhythm disorders as non-sustained supraventricular $(10.2 \%)$ or ventricular tachycardia (1.4\%), atrial fibrillation (4.6\%) and atrioventricular dissociation (6.2\%) (Tables I, II, III).

In Nfx-treated healthy mice, an increase in the corrected QRS length and decrease in the value of the second component of the T wave decay $\left(\mathrm{t}_{2}\right)$ were observed. In healthy mice treated with DPY, a decrease in the heart rate and $\mathrm{R}$ wave amplitude and an increase in the QRS length and in QRS and T axes values was obtained. No ECG qualitative disturbances were induced with both drugs.
In mice with acute Chagas disease treated with DPY, the same ECG disorders as observed in the Chagas control group were seen; however, DPY significantly shortened the QRS length compared with chagasic mice (Table II). Notwithstanding, ECG traces in these mice were improved and they were close to ECG traces from chagasic mice treated with $\mathrm{NfX} 10 \mathrm{mg} / \mathrm{kg}$ plus DPY (Fig. 4). Moreover, the ECG qualitative disturbances were lower compared with the $\mathrm{Nfx} 10 \mathrm{mg} / \mathrm{kg}$ treated group (Fig. 4, Table III).

Chagas disease Nfx-treated mice had improved atrial depolarisation and ventricular repolarisation disorders; however, a significant increase in the $\mathrm{T}$ amplitude decay values at 5 and $20 \mathrm{~ms}$ persisted compared with control mice. Although the QRS length value was significantly reduced in the treated group compared to chagasic mice, the corrected QRS length value was similar to that observed in chagasic mice and significantly higher than in healthy mice, indicating that intraventricular conduction disorders persisted in treated mice (Table II). Noticeably, in these mice, there were increases in ECG qualitative dis-

\section{TABLE I}

Electrocardiographic (ECG) parameters found in untreated and dipyridamole (DPY) or nifurtimox (Nfx) treated healthy NMRI mice

\begin{tabular}{|c|c|c|c|c|c|c|c|}
\hline \multirow[b]{3}{*}{ ECG/Healthy } & \multicolumn{3}{|c|}{ Untreated } & \multicolumn{2}{|c|}{ DPY } & \multicolumn{2}{|c|}{$\mathrm{Nfx}$} \\
\hline & \multirow[b]{2}{*}{ Mean \pm SD } & \multicolumn{2}{|c|}{ Percentile } & \multirow[b]{2}{*}{ Mean \pm SD } & \multirow[b]{2}{*}{$\mathrm{p}$ value } & \multirow[b]{2}{*}{ Mean \pm SD } & \multirow[b]{2}{*}{$\mathrm{p}$ value } \\
\hline & & $10 \%$ & $90 \%$ & & & & \\
\hline HR & $333.8 \pm 103.1$ & 216.6 & 453.5 & $252.8 \pm 21.9$ & $\downarrow 0.04$ & $344.7 \pm 112.6$ & 0.80 \\
\hline PR & $39.7 \pm 7$ & 34.9 & 52.9 & $43.4 \pm 4.7$ & 0.67 & $44.1 \pm 14.6$ & 0.59 \\
\hline PR Bazett & $96.2 \pm 14.1$ & 80 & 108 & $89.1 \pm 9.7$ & 0.19 & $103.3 \pm 23.5$ & 0.24 \\
\hline QRS & $11.2 \pm 1.8$ & 9 & 14.1 & $13.2 \pm 1.1$ & $\uparrow 0.00$ & $12.3 \pm 2.15$ & 0.18 \\
\hline QRS Bazett & $25.7 \pm 3.6$ & 21.5 & 30.5 & $27.2 \pm 2.5$ & 0.26 & $29.3 \pm 4.5$ & $\uparrow 0.02$ \\
\hline QT & $79.7 \pm 42.5$ & 25.9 & 141.4 & $75.5 \pm 29.4$ & 0.79 & $80.4 \pm 70.2$ & 0.97 \\
\hline QTc & $176.8 \pm 79.2$ & 68.4 & 291.9 & $155.6 \pm 63.7$ & 0.49 & $182.5 \pm 136.7$ & 0.86 \\
\hline Pamp & $89.3 \pm 42.9$ & 43.7 & 143.3 & $74.7 \pm 39.4$ & 0.38 & $86.9 \pm 70$ & 0.89 \\
\hline Ramp & $1140 \pm 312.2$ & 740.5 & 1548 & $855.4 \pm 153.5$ & $\downarrow 0.01$ & $1069 \pm 282.1$ & 0.58 \\
\hline Samp & $214 \pm 189.1$ & 18.4 & 411.9 & $267 \pm 161.4$ & 0.47 & $290.3 \pm 241.2$ & 0.34 \\
\hline Tamp & $409.7 \pm 125.6$ & 255.4 & 589.1 & $395.2 \pm 74.1$ & 0.76 & $387.4 \pm 75.8$ & 0.66 \\
\hline $\mathrm{P}$ axis & $47.7 \pm 26.5$ & 8 & 80.5 & $40.2 \pm 38.1$ & 0.44 & $30.6 \pm 18.6$ & 0.13 \\
\hline QRS axis & $83.1 \pm 9.3$ & 75 & 89 & $91.5 \pm 5.1$ & $\uparrow 0.02$ & $77.8 \pm 14.5$ & 0.19 \\
\hline $\mathrm{T}$ axis & $85.9 \pm 3.4$ & 81 & 89 & $89.4 \pm 4.8$ & $\uparrow 0.01$ & $85.5 \pm 7.1$ & 0.77 \\
\hline$t_{1}$ & $4.1 \pm 0.9$ & 2.8 & 5 & $4.4 \pm 0.8$ & 0.39 & $3.7 \pm 1.6$ & 0.40 \\
\hline$t_{1 \%}$ & $90.5 \pm 9.7$ & 75.8 & 100 & $89.4 \pm 6.9$ & 0.76 & $84.6 \pm 22.8$ & 0.19 \\
\hline$t_{2}$ & $67.3 \pm 43.8$ & 38.4 & 113.3 & $90.4 \pm 76.3$ & 0.14 & $31.2 \pm 48.3$ & $\downarrow 0.01$ \\
\hline$t_{2 \%}$ & $9.4 \pm 9.7$ & 0 & 24.1 & $10.6 \pm 3.8$ & 0.87 & $15.3 \pm 22.8$ & 0.26 \\
\hline Tad $5 \mathrm{~ms}$ & $34.2 \pm 7.4$ & 23.9 & 43 & $34.6 \pm 5.5$ & 0.94 & $34.7 \pm 11.2$ & 0.92 \\
\hline Tad $10 \mathrm{~ms}$ & $18.3 \pm 6.4$ & 8.9 & 26.5 & $18.4 \pm 4.4$ & 0.85 & $18.9 \pm 15.1$ & 0.98 \\
\hline Tad 20ms & $11.5 \pm 6.2$ & 2.6 & 18.1 & $10.8 \pm 4.5$ & 0.69 & $12.4 \pm 16.8$ & 0.87 \\
\hline $\mathrm{Tad} 40 \mathrm{~ms}$ & $8.1 \pm 5.5$ & 1 & 14.9 & $8.6 \pm 4.5$ & 0.99 & $13.7 \pm 7.9$ & 0.09 \\
\hline Tad $60 \mathrm{~ms}$ & $6 \pm 5.3$ & 0 & 11.8 & $6.8 \pm 1.3$ & 0.09 & $9.1 \pm 4$ & 0.40 \\
\hline
\end{tabular}

t: T wave decay constant; Tad: T amplitude decay at each indicated time; arrows down or up indicate a decrease or increase of the ECG parameters. P values shown are related to values obtained in untreated mice. Doses were 30 and $10 \mathrm{mg} / \mathrm{Kg}$ of DPY and Nfx, respectively. 


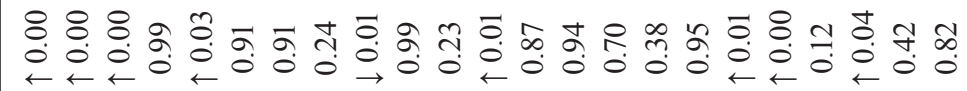

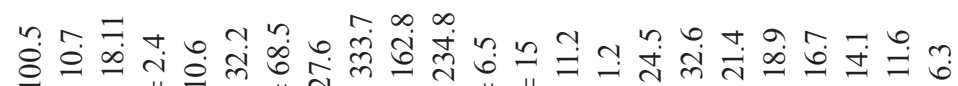
H H H H H H H H H H H H H H H H H H H H H H

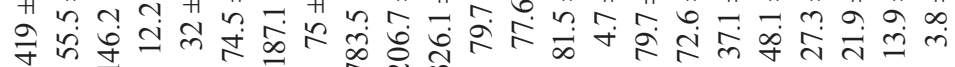

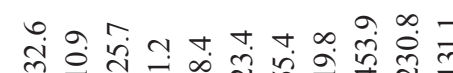
H H H H H H H H H H H H H H H

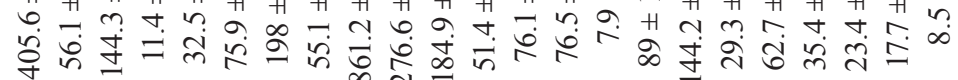

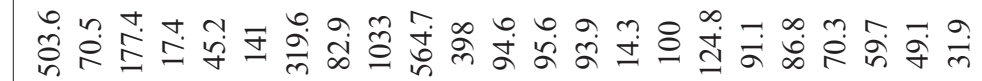

ปิ

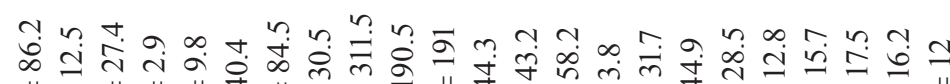

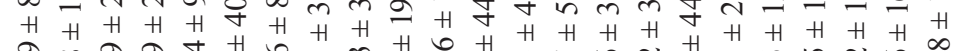

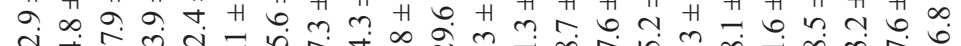

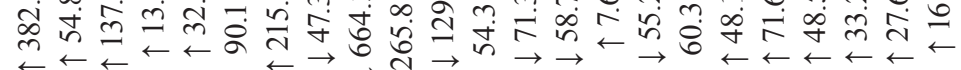

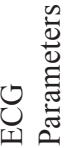
$\simeq \approx$ సี 
TABLE III

Electrocardiographic (ECG) rhythm, conduction and repolarisation qualitative disorders

\begin{tabular}{|c|c|c|c|c|c|c|c|c|c|c|}
\hline \multirow[b]{3}{*}{ Heart rhythm disorders } & \multicolumn{10}{|c|}{ Group } \\
\hline & \multicolumn{2}{|c|}{ Healthy } & \multicolumn{2}{|c|}{ Chagasic } & \multicolumn{2}{|c|}{ Nifurtimox (Nfx) } & \multicolumn{2}{|c|}{ Dipyridamole (DPY) } & \multicolumn{2}{|c|}{$\mathrm{DPY}+\mathrm{Nfx}$} \\
\hline & $\mathrm{n}$ & $(\%)$ & $\mathrm{n}$ & $(\%)$ & $\mathrm{n}$ & $(\%)$ & $\mathrm{n}$ & $(\%)$ & $\mathrm{n}$ & $(\%)$ \\
\hline Sinus extrasystole & 6 & 8.1 & 32 & 23.5 & 2 & 25 & 2 & 25 & 0 & 0 \\
\hline Ventricular extrasystole & 0 & 0 & 29 & 21.3 & 3 & 37.5 & 0 & 0 & 1 & 12.5 \\
\hline Nodal extrasystole & 0 & 0 & 4 & 2.9 & 1 & 12.5 & 1 & 12.5 & 0 & 0 \\
\hline Supraventricular tachycardia & 0 & 0 & 14 & 10.2 & 0 & 0 & 0 & 0 & 0 & 0 \\
\hline Ventricular tachycardia & 0 & 0 & 2 & 1.4 & 2 & 25 & 0 & 0 & 0 & 0 \\
\hline Atrial ectopics beats & 0 & 0 & 8 & 6.2 & 0 & 0 & 0 & 0 & 0 & 0 \\
\hline Atrioventricular dissociation & 0 & 0 & 8 & 6.2 & 0 & 0 & 0 & 0 & 0 & 0 \\
\hline Atrial fibrillation & 0 & 0 & 6 & 4.6 & 0 & 0 & 0 & 0 & 0 & 0 \\
\hline Second-degree AV block & 0 & 0 & 3 & 2.3 & 0 & 0 & 0 & 0 & 0 & 0 \\
\hline Two P waves & 0 & 0 & 27 & 19.8 & 7 & 87.5 & 3 & 37.5 & 5 & 62.5 \\
\hline Bifid P wave & 0 & 0 & 24 & 17.6 & 0 & 0 & 0 & 0 & 1 & 12.5 \\
\hline Post-depolarisation (U) wave & 0 & 0 & 89 & 65.4 & 4 & 50 & 2 & 25 & 3 & 37.5 \\
\hline Flattened T wave & 0 & 0 & 12 & 8.8 & 3 & 37.5 & 0 & 0 & 0 & 0 \\
\hline
\end{tabular}

Total $\mathrm{n}$ were 74 and 136 for healthy and chagasic mice respectively; for treated groups were eight each one. Nfx and DPY doses were 10 and $30 \mathrm{mg} / \mathrm{Kg}$ respectively.
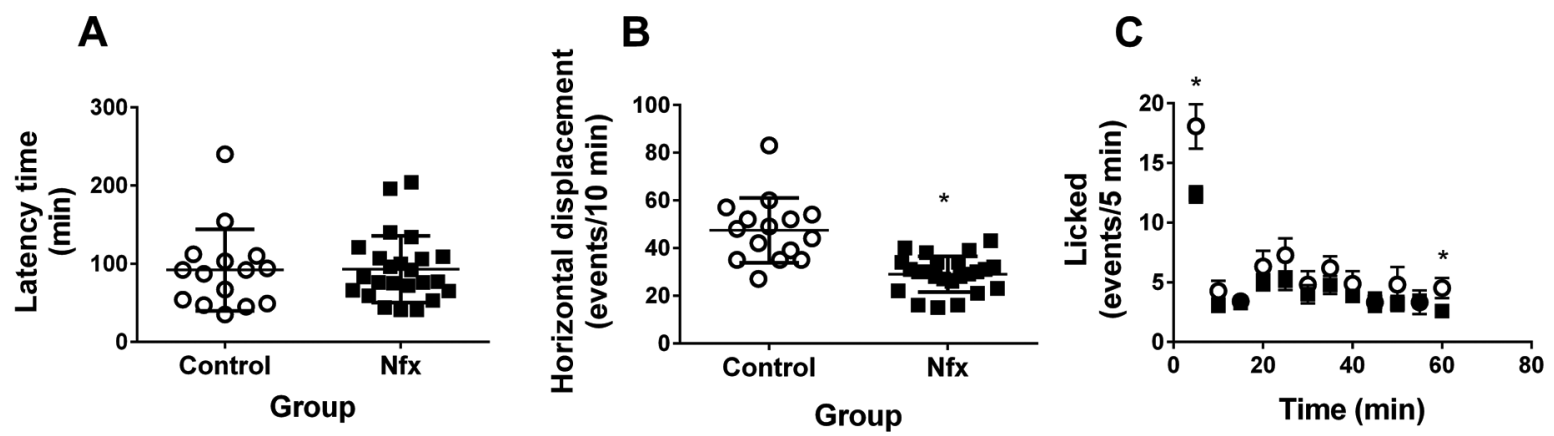

Fig. 3: assessment of nifurtimox (Nfx) side effects by behavioural tests in healthy mice. (A) Shows results obtained from the hot plate test, which assesses cutaneous pain sensitivity, and no significant difference was observed between healthy mice and healthy mice treated with $40 \mathrm{mg} / \mathrm{kg}$ Nfx for 30 days. (B) Shows results obtained from the open field test, which assesses horizontal and vertical motility; Nfx-treated healthy mice displayed significantly less motility compared to healthy untreated mice. (C) Shows results obtained from the formalin test, which assesses neural and inflammatory pain sensitivity; licking was only significantly higher at 5 and 45 min in Nfx-treated healthy mice; however, in the other time windows, no differences were observed.

orders compared with all groups (Table III), especially severe rhythm disorders, such as non-sustained ventricular tachycardia and multiples ventricular ectopics, as well as ischaemic disorders such as flattened or inverted $\mathrm{T}$ wave and post-depolarisation wave (Fig. 4, Table III).

In mice with acute Chagas disease treated with $\mathrm{Nfx}$ $10 \mathrm{mg} / \mathrm{kg}$ combined with DPY, an improvement in most of the analysed parameters was observed. However, a persistence of the prolonged PR interval was observed and ventricular repolarisation improvement was partial because an increase in the $\mathrm{T}$ wave decay amplitudes at 5 and 10 msec persisted compared to values obtained in healthy mice (Table II). As expected, ECG traces were similar to healthy mice; however, ECG qualitative disturbances were higher in the Chagas mice (Fig. 4, Table III).
Histopathology - The hearts from the groups treated with $\mathrm{Nfx} 10$ or $40 \mathrm{mg} / \mathrm{kg}$, alone or in combination with DPY, had a significant decrease in their weights compared with the Chagas control group. Spleens from groups treated with Nfx $40 \mathrm{mg} / \mathrm{kg}$ alone, Nfx $10 \mathrm{mg} / \mathrm{kg}$ plus DPY and Nfx $40 \mathrm{mg} / \mathrm{kg}$ plus DPY had a significant decrease in the weight compared with the control Chagas group. In mice treated with $\mathrm{Nfx} 40 \mathrm{mg} / \mathrm{kg}$, a significant decrease in liver weight was also observed (Table IV).

In groups treated with $\mathrm{Nfx} 10$ and $40 \mathrm{mg} / \mathrm{kg}$ alone or in combination with DPY, a significant decrease in inflammatory cell infiltrates was observed compared to the control group. The DPY-treated group showed an inflammatory cell infiltrate similar to the Chagas control group (Fig. 5, Table IV). 


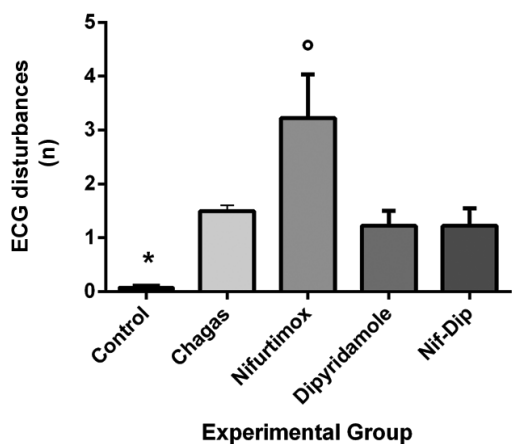

B1

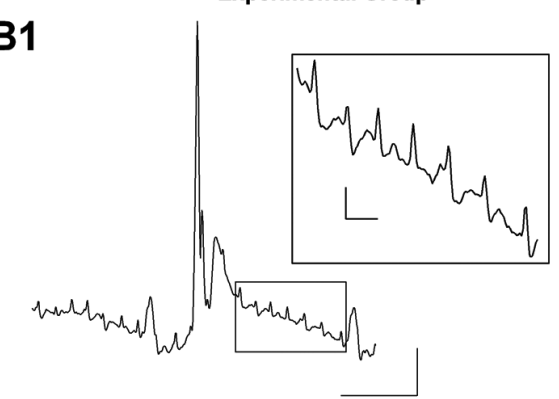

C1

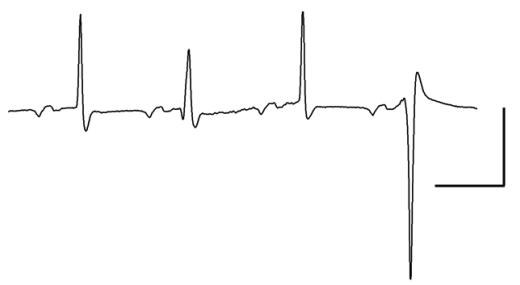

D1

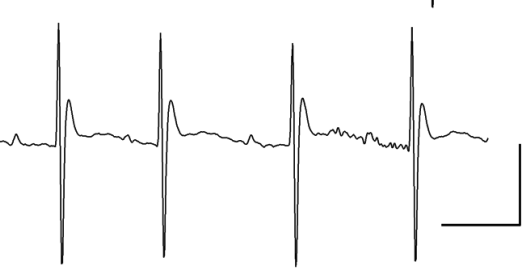

A1

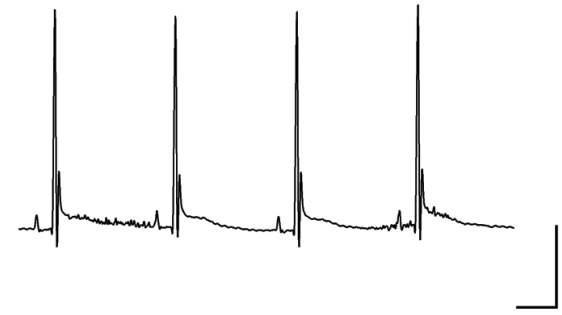

B2

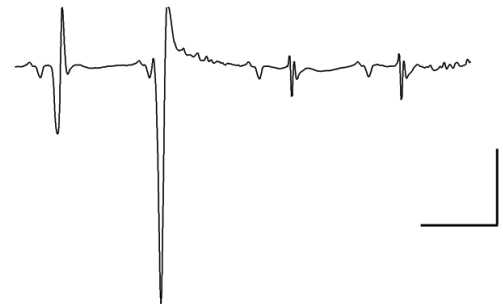

C2

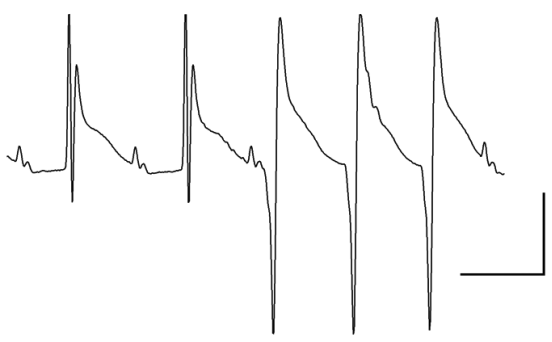

D2

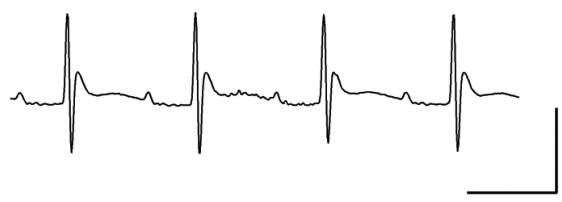

E2

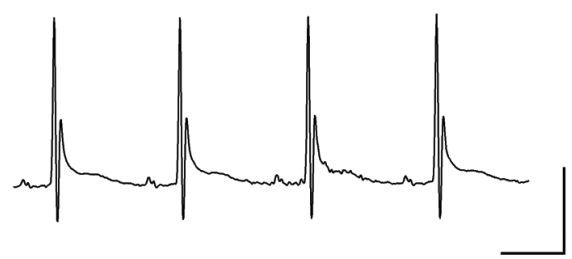

Fig. 4: typical electrocardiographic (ECG) traces and qualitative ECG disorders observed in healthy, untreated and treated chagasic mice. The mean \pm standard error (SEM) of the qualitative ECG disorders (rhythm, conduction and repolarisation disorders) observed in mice of the different experimental groups are shown in the upper panel on the left. Healthy mice have practically no disorders, whereas the group of chagasic mice treated with nifurtimox (Nfx) had a significantly greater increase in these disorders compared with the remaining groups. In panel A1, we show a typical record of a healthy mouse. Traces of mice with chagasic myocarditis are shown in panels B1 and B2; in B1, we can observe low-voltage QRS complexes with a Rr' wave suggestive of His intranodal block and multiple rhythmical atrial ectopics that are magnified in the inserted box suggestive of atrial flutter; in B2, we can perceive a complex rhythm disorder with ventricular extrasystoles, a very low voltage QRS complex, a deep S wave and a negative T wave. Traces of mice with chagasic myocarditis treated with $\mathrm{Nfx}$ at doses of $10 \mathrm{mg} / \mathrm{kg}$ of body weight are shown in panels $\mathrm{C} 1$ and $\mathrm{C} 2$ where there is a worsening in the qualitative disorders. In $\mathrm{Cl}$, there is atrioventricular dissociation, a negative-positive biphasic $\mathrm{P}$ wave, and diminished voltage QRS complex with variable morphology, including ventricular extrasystole and negative $\mathrm{T}$ wave. In $\mathrm{C} 2$, there is a double $\mathrm{P}$ wave and peaked $\mathrm{T}$ wave with an evident delay in its decay, which delineates a post depolarisation phenomenon (U wave) and no sustained ventricular tachycardia. In D1 and D2, traces from mice with chagasic myocarditis treated with dipyridamole are shown with clear improvement in the qualitative aspects of the electrocardiogram; however, repolarisation disorders and a decrease in the voltage of the QRS complex persist (D2). Traces of mice with chagasic myocarditis treated with $\mathrm{Nfx} 10$ $\mathrm{mg} / \mathrm{kg}$ plus dipyridamole are shown in E1 and E2, where there are practically no ECG disorders (compare with trace A1). *: indicates $\mathrm{p}<0.05$ when comparing the control with the other experimental groups, ${ }^{\circ}:$ it indicates $\mathrm{p}<0.05$ when comparing the group treated with Nfx compared to the other experimental groups. The vertical bars are equivalent to $500 \mu \mathrm{V}$ and horizontal bars are $100 \mathrm{~ms}$ for all traces, by except of panel $\mathrm{B} 1 \mathrm{where}$ vertical and horizontal bars are $150 \mu \mathrm{V}$ or ms, respectively; also in the insert vertical bar is equivalent to $50 \mu \mathrm{V}$ and the horizontal bar is to $25 \mathrm{~ms}$. 
In groups treated with $\mathrm{Nfx} 10$ and $40 \mathrm{mg} / \mathrm{kg}$ alone or in combination with DPY, a significant decrease in the amastigote nest number was observed, while the group treated with DPY alone showed a similar number as in the Chagas control group (Fig. 5, Table IV).

Likewise, in the groups treated with Nfx 10 or 40 $\mathrm{mg} / \mathrm{kg}$ associated with DPY, a significant decrease in the fibrosis was observed compared to the control Chagas group (Fig. 6, Table IV).

Plasma enzymes - In the Chagas control and DPYtreated groups, a significant increase in the serum CKMB activity was observed, while mice treated with Nfx alone at both doses or combined with DPY had decreased CKMB levels, achieving values similar to those in healthy mice. The SGOT serum activities were also significantly increased in the Chagas control, DPY and $\mathrm{Nfx} 10 \mathrm{mg} / \mathrm{kg}$ groups, while in mice treated with Nfx 40 $\mathrm{mg} / \mathrm{kg}$ alone or in combination with DPY at both doses, the serum SGOT levels were significantly decreased and similar to healthy mice (Table IV).

Behavioural effect of Nfx in healthy mice - Mice treated with Nfx exhibit similar behaviour in the nociceptive hot plate test and formalin test late licking behaviour; however, a significant decrease in early licking behaviour during the formalin test was observed. Moreover, in the group treated with $\mathrm{Nfx} 40 \mathrm{mg} / \mathrm{kg}$, a significant decrease in horizontal displacement movements was observed compared with healthy mice (Fig. 3).

\section{DISCUSSION}

In the present paper, we confirm that Nfx is an efficient trypanocidal drug, although its effect depended on the dose. In our animal model, the dose of $40 \mathrm{mg} / \mathrm{kg}$ was therapeutic; parasitaemia was suppressed on day 20 post-treatment and remained negative until the end of the experiment. Also, 92\% of the treated mice survived and showed no cardiomegaly, hepatomegaly or splenomegaly, and heart histopathological studies did not reveal free or nest amastigotes, while the inflammatory infiltrate was mild. By contrast, $\mathrm{Nfx}$ at $10 \mathrm{mg} / \mathrm{kg}$ was subtherapeutic, as revealed by the $80 \%$ mortality, continuous parasitaemia increase in the first three weeks of treatment, persistence of amastigotes in heart tissue, splenomegaly, abnormal EKG and elevated blood SGOT activity. The $40 \mathrm{mg} / \mathrm{kg} \mathrm{Nfx}$ therapeutic dose is above the usually recommended dose of $10 \mathrm{mg} / \mathrm{kg}$ for treating Chagas disease in humans.

Despite being a drug that was discovered in the last century, there have been few systematic, comprehensive and complete studies in murine models on the therapeutic effect of Nfx. The data presented here represent one of the most comprehensive studies to date. Other studies have used high doses of the drug, obtaining conflicting results, while Bustamante et al. (2014) obtained a 95 to $100 \%$ cure rate at $100 \mathrm{mg} / \mathrm{kg}$ in a continuous or intermittent protocol applied in C57BL/6 (Ly5.2) mice and Wong-Baeza et al. (2015) obtained a slight decrease in parasitaemia with the same dose for 50 days in NIH albino mice. This discrepancy may be explained by the strains of mice used; however, the response could also 


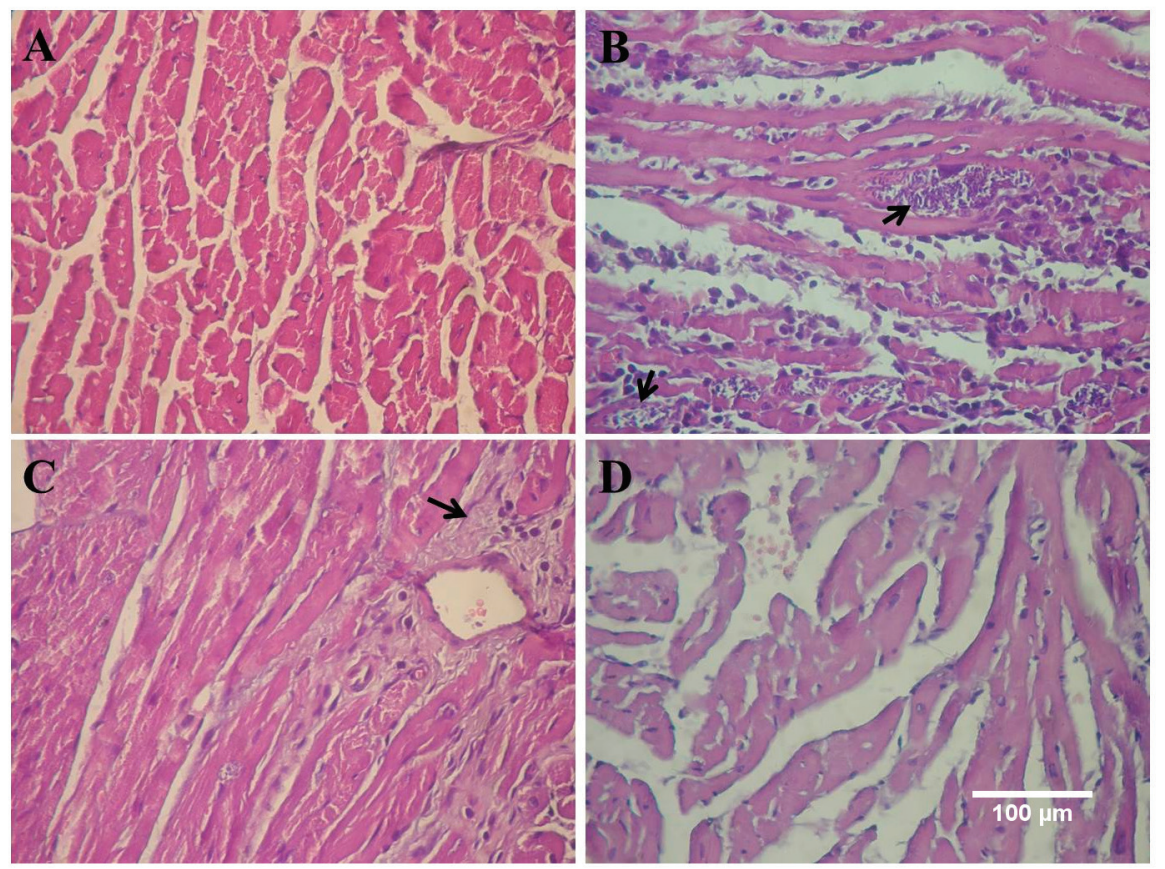

Fig. 5: histopathological findings in haematoxylin-eosin stained heart tissue. (A) Shows a heart tissue sample from healthy mice; (B) from Trypanosoma cruzi-infected mice where amastigote nests (arrows), mononuclear infiltrate and myocitolisis can be observed; (C) $40 \mathrm{mg} / \mathrm{kg} \mathrm{Nfx}$-treated mice lacked amastigotes present, but fibrosis areas were present; and (D) $40 \mathrm{mg} / \mathrm{kg} \mathrm{Nfx}$ plus $30 \mathrm{mg} / \mathrm{kg}$-treated mice lacked evident lesions or parasite forms.
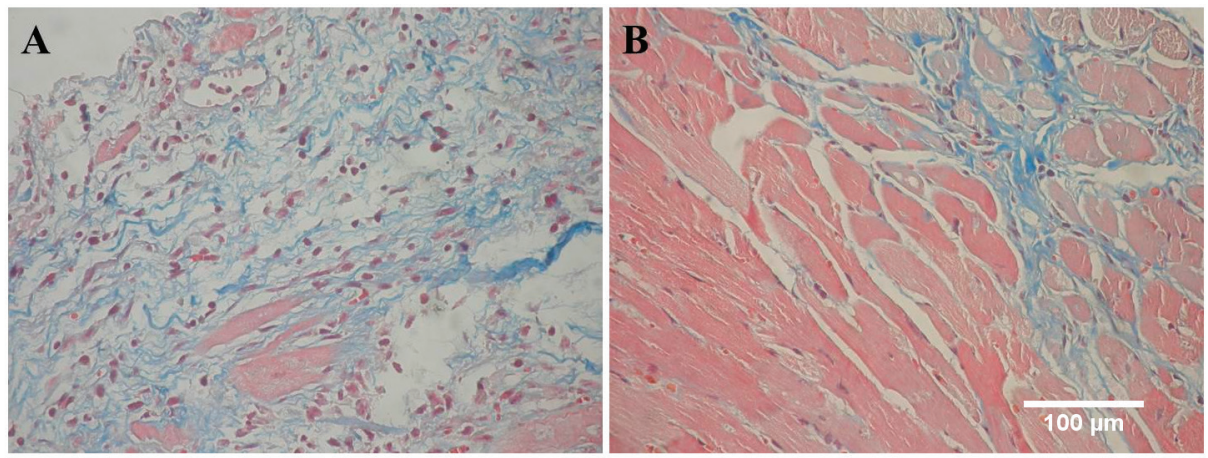

Fig. 6: histopathological findings in heart tissue stained by Masson's trichrome technique. (A) Shows a sample from Trypanosoma cruzi-infected mice and (B) from $40 \mathrm{mg} / \mathrm{kg}$ nifurtimox ( $\mathrm{Nfx}$ )-treated mice; note that there is extensive lax fibrosis with persistent inflammatory infiltrate and an absence of cardiomyocytes in chagasic heart sections, while in the heart sections of mice treated with $\mathrm{Nfx}$, the fibrosis is less extensive, compact and interfibrilar.

depend on the assayed strain of $T$. cruzi, which is apparent from the work of Andrade et al. (1985), who found that type I strains (high and early parasitaemia with macrophage tropism) had high susceptibility $(56 \pm 16 \%$ cure), type II strains (high and late parasitaemia with heart tropism) had medium to high susceptibility (52 \pm $11 \%$ cure), and type III strains (low parasitaemia with skeletal muscle tropism) had low susceptibility $(0.45 \pm$ $0.45 \%$ cure) to therapeutic schemes based on Nfx 200 $\mathrm{mg} / \mathrm{kg}$ for four days followed by $50 \mathrm{mg} / \mathrm{kg}$ for five days/ week for 90 days. Furthermore, Faúndez et al. (2008) found decreased parasitaemia at doses of 2.5 and $10 \mathrm{mg} /$ $\mathrm{kg}$ with 25 and $100 \%$ survivals, respectively.

When comparing the effectiveness obtained in this work in cultured epimastigotes $\left(\mathrm{IC}_{50}=21.53 \mu \mathrm{M}\right)$ with $\mathrm{Nfx}$ doses used in in vivo experiments, where 10 and $40 \mathrm{mg} / \mathrm{kg}$ are equivalent to 34.8 and $139.23 \mu \mathrm{mol} / \mathrm{kg}$, respectively, these data confirm that $10 \mathrm{mg} / \mathrm{kg}$ is a subtherapeutic dose, while $40 \mathrm{mg} / \mathrm{kg}$ is almost a therapeutic dose based on the $\mathrm{IC}_{50}$. However, when we analysed the drug bioavailability, which is very low (5.25\%) due to rapid and extensive metabolism in the liver, where it is subjected to nitroreduction by cytochrome P-450 reductase, the serum concentration of Nfx achieved after an oral dose of $15 \mathrm{mg} / \mathrm{kg}(52 \mu \mathrm{mol} /$ $\mathrm{kg}$ ) would be $2.73 \mu \mathrm{M}$ serum (Paulos et al. 1989), which is far below the therapeutic concentrations. Therefore, the drug potency in vivo is increased. Increased potency could be explained through drug metabolism during which host cells generate free radicals that facilitate parasite lysis (Letelier et al. 2004, Bartel et al. 2007). 
Two points have been crucial to the reluctance to Nfx routine use: the reasoned but controversial lack of efficacy and frequent side effects (Murcia et al. 2012). In this paper, we evaluated the side effects of $\mathrm{Nfx}$ at a dose of $40 \mathrm{mg} / \mathrm{kg}$ in healthy mice and found slight but significant disturbances in the red blood cell count (even when diminished, it remained within normal limits for the species), decreased motility and decreased early nociceptive response to formalin; we did not observe disorders in animal weight, in the counting and distribution of white blood cells and in nociception to thermal stimuli. Therefore, our results indicate that psychic excitability and polyneuropathies with paraesthesia observed in humans are not observed in mice treated with Nfx.

In a phase I study performed in paediatric patients on the therapeutic effect of Nfx alone or in combination with cyclophosphamide and topotecan for treating refractory neuroblastoma with multiple relapses, it was determined that the maximum tolerated dose in these compromised patients was $30 \mathrm{mg} / \mathrm{kg}$ (Sholler et al. 2011), which is very close to the therapeutic dose raised in the present paper. In addition, we observed that chagasic mice treated with $\mathrm{Nfx} 40 \mathrm{mg} / \mathrm{kg}$ had an increased weight and maintained a healthy trophism in terms of the coat appearance and instinctive behaviours. By contrast, in chagasic mice treated with $\mathrm{Nfx} 10 \mathrm{mg} / \mathrm{kg}$, alopecia, piloerection, crusted lesions and defensive muscle tone were observed (results not shown). To reconcile data reported in the literature with data reported in the present study, we propose that the side effects are a greater reflection of concurrent Chagas disease pathophysiological phenomena than the drug itself. In fact, the toxic effect of Nfx may depend on its metabolism by host cells and parasites.

Within reductions catalysed by the oxidative cytochrome P450 system in the host, the best known is the single electron reduction of nitro groups, leading to the formation of -NO2-, which can undergo redox recycling and generate radical superoxide anion (O2-) and hydroxyl radicals $\left(\mathrm{HO}^{-}\right)$in the presence of $\mathrm{O}_{2}$ and can generate oxidative stress (Letelier et al. 2004, Bartel et al. 2007). The cytochrome P450 oxidative system is strongly expressed in leukocytes; therefore, in an inflammatory process such as Chagas disease, treatment with Nfx in the presence of inflammatory cells could amplify oxidative stress and may explain the increase in ECG disturbances observed in chagasic mice treated with subtherapeutic doses. Using this dose, the inflammatory cell infiltrate continues given the persistence of the parasite in tissues and the side effects are therefore dependent on oxidative stress generated by the metabolism of Nfx in inflammatory cells. With therapeutic doses, the parasite is removed; inflammation ceases, and oxidative stress induced by Nfx metabolism in leukocytes is prevented, decreasing collateral side effects.

In this paper, we demonstrate for the first time that DPY has a trypanocidal effect in vitro on $T$. cruzi epimastigote proliferation and decreases parasitaemia in infected NMRI mice. However, the amastigote density in cardiac tissue was not affected by the drug. The effect of DPY on epimastigote proliferation has previously been reported in $T$. brucei, where an $\mathrm{IC}_{50}$ of $30 \mu \mathrm{M}$ was obtained (de Koning et al. 2012). The dose of DPY used in the in vivo model was subtripanocidal because $30 \mathrm{mg} / \mathrm{kg}$ equals 60 $\mu \mathrm{M}$. Moreover, assuming a bioavailability between 37 and $66 \%$, we would reach serum concentrations between 22.2 and $39.6 \mu \mathrm{M}$, respectively, which is 9.39 to 16.75 times lower than the $\mathrm{IC}_{50}$ in vitro. At these doses, between 5 and $15 \%$ of the maximum trypanocidal effect would be obtained, which is in perfect agreement with the results obtained in vivo with the use of DPY alone. The lack of effect on tissue amastigotes may reflect that these parasitic forms do not depend on the extracellular adenosine as a source of endogenous purines; therefore, they are not sensitive to DPY (Guimarães \& Gutteridge 1987).

Notwithstanding the trypanocidal action of DPY, its functional effect should be considered; like other authors, we think that the cardiovascular benefits of this drug have been undervalued, and the beneficial effect observed in this study could be related to its mechanism of action. First, DPY induces coronary vasodilation mediated by nitric oxide and inhibits platelet aggregation mediated by PGI2. This effect results from PDE5 enzyme inhibition, causing elevation of the intracellular cAMP and cGMP levels (Kim \& Liao 2008). Moreover, by blocking nucleotide transporters, DPY elevates extracellular adenosine levels, which act on A2 receptors and potentiate intracellular elevation of cAMP levels (Layland et al. 2014). The consequence of this mode of action is improved coronary irrigation and prevention against new platelet and hematic thrombi formation, counteracting pathophysiological phenomena related to diffuse ischaemia in the coronary microvasculature. Moreover, it has been reported that DPY improves cardiac contractility of hypokinetic areas and ejection fraction in patients with Chagas cardiomyopathy (Kuschnir et al. 1983).

Second, DPY is cardioprotective, an effect mediated by adenosine acting on $\mathrm{A} 1$ and $\mathrm{A} 3$ receptors, which would optimize cardiac work according to the availability of energy sources, inhibit early apoptotic phenomena and prevent the occurrence of lethal arrhythmias (Layland et al. 2014). In this sense, it has been reported that endogenous adenosine acting on A1 receptors generates negative chronotropic and dromotropic effects, reducing the incidence of ventricular arrhythmias induced by ischaemia-reperfusion in isolated rat hearts (Lee et al. 1994).

Third, DPY is an immunomodulator drug, which is mainly mediated by $\mathrm{A} 2 \mathrm{~A}$ receptors. Adenosine acting on $\mathrm{A} 1$ and $\mathrm{A} 3$ receptors promotes the recruitment of immature dendritic cells to sites of inflammation, while it promotes the differentiation of T cells to an anti-inflammatory $\mathrm{TH} 2$ profile via $\mathrm{A} 2 \mathrm{~A}$ receptors. This scenario promotes decreased levels of IL6 and TNFa, while the IL10 levels are increased. This balance promotes an anti-inflammatory state in heart tissue that counteracts necrotic phenomena, fibrosis and cardiac remodelling associated with severe inflammation (Haskó et al. 2008). Elevated levels of TNF- $\alpha$ and IL- 6 have been associated with advanced stages of Chagas disease and negatively with the cardiac ejection fraction (Mendoza et al. 2005, López et al. 2006), while high levels of IL-10 have been observed in asymptomatic patients in the indeterminate phase of Chagas disease, and patients who have developed cardiac disorders have reduced levels of this cytokine (Sousa et al. 2014). 
Finally, the molecular structure of DPY allows it to accept electrons, acting as a free radical scavenger, whose capacity is even greater than $\alpha$-tocopherol and vitamin C (Kim \& Liao 2008). During Chagas cardiomyopathy development, the myocardium is continuously exposed to injury caused by the release of free radical products of mitochondrial damage (Vyatkina et al. 2004); therefore, the beneficial effect of DPY could be associated with its antioxidant capacity.

In conclusion, in the present study, we show that 40 $\mathrm{mg} / \mathrm{kg}$ is the therapeutic trypanocidal dose of $\mathrm{Nfx}$ in NMRI mice with acute Chagas disease, while the $10 \mathrm{mg} /$ $\mathrm{kg}$ dose is subtherapeutic and has little utility in preventing or reversing Chagas cardiomyopathy development in an NMRI murine model. The side effects observed in healthy mice are mild; therefore, in NMRI mice, severe side effects may be related to drug metabolism by persistent inflammatory cells. DPY enhanced the trypanocidal effect of Nfx, transforming subtherapeutic doses to therapeutic levels, and this effect could be related to their trypanocidal capacity and its mechanism of action related to the prevention or reversal of pathophysiological phenomena related to microvascular theory. Because of their anti-inflammatory, immunomodulatory and antioxidant effects, these medications may improve cardiac function.

The results obtained here in NMRI mice should be interpreted with caution when considering clinical implications in humans with Chagas disease. For example, the $10 \mathrm{mg} / \mathrm{kg} \mathrm{Nfx}$ dose is subtherapeutic in mice, but this is not applicable for other species, including humans, because the same drug dose will produce different blood levels and tissue concentrations in different species because the bioavailability and biodistribution of the drug differ between different species.

Notwithstanding, given the extensive experience that medical doctors have regarding the clinical use of DPY, its wide therapeutic window, safety and mechanism of action make it an interesting drug that should be tested as an adjunct drug in the treatment of Chagas disease in chronic animal models and then its value assessed in moving on to clinical trials.

\section{AUTHORS' CONTRIBUTION}

SS - Conception and drafting of the general project, execution, analysis and interpretation of in vitro and in vivo parasitological experiments, histopathological experiments, electrocardiographic and biochemical experiments, participated in writing and gave final manuscript approval; $\mathrm{PC}$ - execution and analysis of behavioural experiments, writing and interpretation of behavioural experiments and final approval of the manuscript; EG - execution and analysis of in vivo parasitological and electrocardiographic experiments, wrote and interpreted electrocardiographic and in vivo parasitological experiments and gave final approval of the manuscript; CA - execution of in vitro and in vivo parasitological experiments, writing and interpretation of in vitro parasitological experiments and final approval of the manuscript; DY - execution and analysis of electrocardiographic experiments, writing and interpretation of experiments and electrocardiographic data, and writing, critical review and final approval of the manuscript; RB - execution and analysis of biochemical experiments, writing and interpretation of biochemical experiments, and writing, critical review and final approval of the manuscript; CR - cogeneral director of the project, participated in the conception and analysis of the project for its approval, participated in the design, execution, monitoring, analysis and interpretation of histopathological and in vitro and in vivo parasitological experiments, participated in consolidating and enriching the writing as well as in the critical review and final approval of the manuscript; RB-C - director general of the project, participated in the design and drafting of the project for approval, participated in the design, execution, monitoring, analysis and interpretation of in vitro and in vivo parasitological experiments, histopathological, electrocardiographic, behavioural and biochemical experiments, participated in the configuration of the final manuscript, in consolidating and enriching his writing, and in the critical review and final approval of the manuscript.

\section{REFERENCES}

Alarcón de Noya B, Díaz-Bello Z, Colmenares C, Ruiz-Guevara R, Mauriello L, Muñoz-Calderón A, et al. Update on oral Chagas disease outbreaks in Venezuela: epidemiological, clinical and diagnostic approaches. Mem Inst Oswaldo Cruz. 2015; 110(3): 377-86.

Andrade SG, Magalhães JB, Pontes A. Evaluation of chemotherapy with benznidazole and nifurtimox in mice infected with Trypanosoma cruzi strains of different types. Bull World Health Organ. 1985; 63(4): 721-6.

Añez N, Crisante G, Rojas A. Update on Chagas disease in Venezuela - A Review. Mem Inst Oswaldo Cruz. 2004; 99(8): 781-7.

Bartel LC, de Mecca MM, Fanelli SL, de Castro CR, Diaz EG, Castro JA. Early nifurtimox-induced biochemical and ultrastructural alterations in rat heart. Hum Exp Toxicol. 2007; 26(10): 781-8.

Bustamante JM, Craft JM, Crowe BD, Ketchie SA, Tarleton RL. New, combined, and reduced dosing treatment protocols cure Trypanosoma cruzi infection in mice. J Infect Dis. 2014; 209(1): 150-162.

Coura JR, Borges-Pereira J. Chronic phase of Chagas disease: why should it be treated? A comprehensive review. Mem Inst Oswaldo Cruz. 2011; 106(6): 641-5.

de Koning HP, Gould MK, Sterk GJ, Tenor H, Kunz S, Luginbuehl E, et al. Pharmacological validation of Trypanosoma brucei phosphodiesterases as novel drug targets. J Infect Dis. 2012; 206(2): 229-37.

Dias JCP, Ramos Jr AN, Gontijo ED, Luquetti A, Shikanai-Yasuda MA, Coura JR, et al. II Consenso Brasileiro em doença de Chagas, 2015. Epidemiol Serv Saude. 2016; 49(núm esp.): 7-86.

Faúndez M, López-Muñoz R, Torres G, Morello A, Ferreira J, Kemmerling $\mathrm{U}$, et al. Buthionine sulfoximine has anti-Trypanosoma cruzi activity in a murine model of acute Chagas' disease and enhances the efficacy of nifurtimox. Antimicrob Agents Chemother. 2008; 52(5): 1837-9.

Guimarães RC, Gutteridge WE. Purine base uptake in Trypanosoma cruzi: adaptations and effects of inhibitors. Braz J Med Biol Res. 1987; 20(1): 1-10.

Haskó G, Linden J, Cronstein B, Pacher P. Adenosine receptors: therapeutic aspects for inflammatory and immune diseases. Nat Rev Drug Discov. 2008; 7(9): 759-70.

Kim HH, Liao JK. Translational therapeutics of dipyridamole. Arterioscler Thromb Vasc Biol. 2008; 28(3): s39-42.

Kuschnir E, Sgammini H, Castro R, Evequoz C, Ledesma R. Miocardiopatía chagásica crónica: efectos del dipiridamol sobre la dinámica ventricular. Arq Bras Cardiol. 1983; 41(5): 373-8. 
Layland J, Carrick D, Lee M, Oldroyd K, Berry C. Adenosine: physiology, pharmacology, and clinical applications. JACC Cardiovasc Interv. 2014; 7(6): 581-91.

Lee Y, Chern J, Yen M. Antiarrhythmic effects of BN $\square 063$, a newly synthesized adenosine A1 agonist, on myocardial ischaemia in rats. Br J Pharmacol. 1994; 112(4): 1031-6.

Letelier ME, Izquierdo P, Godoy L, Lepe AM, Faúndez M. Liver microsomal biotransformation of nitro-aryl drugs: mechanism for potential oxidative stress induction. J Appl Toxicol. 2004; 24(6): 519-25.

López L, Arai K, Giménez E, Jiménez M, Pascuzo C, RodríguezBonfante $\mathrm{C}$, et al. Las concentraciones séricas de interleucina- 6 y proteína $\mathrm{C}$ reactiva se incrementan a medida que la enfermedad de Chagas evoluciona hacia el deterioro de la función cardíaca. Rev Española Cardiol. 2006; 59(1): 50-6.

Medrano-Mercado N, Ugarte-Fernández R, Butrón V, Uber-Busek S, Guerra HL, Araújo-Jorge TC, et al. Urban transmission of Chagas disease in Cochabamba, Bolivia. Mem Inst Oswaldo Cruz. 2008; 103(5): 423-30.

Mendoza EA, Bonfante CR, Camacho I, Martínez J, Perdomo T, Cabrera A, et al. Pacientes con cardiomiopatía dilatada chagásica y cardiopatía no chagásica presentan niveles elevados del factor de necrosis tumoral a. Invest Clin. 2005; 46(3): 229-40.

Murcia L, Carrilero B, Segovia M. Limitations of currently available Chagas disease chemotherapy. Rev Esp Quimioter. 2012; 25(1): 1-3.

Palmer TM, Trevethick MA. Suppression of inflammatory and immune responses by the $\mathrm{A}(2 \mathrm{~A})$ adenosine receptor: an introduction. Br J Pharmacol. 2008; 153(Suppl. 1): S27-34.

Paulos C, Paredes J, Vasquez I, Thambo S, Arancibia A, GonzálezMartin G. Pharmacokinetics of a nitrofuran compound, nifurtimox, in healthy volunteers. Int J Clin Pharmacol Ther Toxicol. 1989; 27(9): 454-7.
Requena-Méndez A, Aldasoro E, de Lazzari E, Sicuri E, Brown M, Moore DA, et al. Prevalence of Chagas disease in Latin-American migrants living in Europe: a systematic review and metaanalysis. PLoS Negl Trop Dis. 2015; 9(2): e0003540.

Rossi MA, Tanowitz HB, Malvestio LM, Celes MR, Campos EC, Blefari $\mathrm{V}$, et al. Coronary microvascular disease in chronic Chagas cardiomyopathy including an overview on history, pathology, and other proposed pathogenic mechanisms. PLoS Negl Trop Dis. 2010; 4(8): e674.

Sguassero Y, Cuesta CB, Roberts KN, Hicks E, Comandé D, Ciapponi A, et al. Course of chronic Trypanosoma cruzi Infection after treatment based on parasitological and serological tests: a systematic review of follow-up studies. PLoS ONE. 2015; 10(10): e0139363.

Sholler GLS, Bergendahl GM, Brard L, Singh AP, Heath BW, Bingham $\mathrm{PM}$, et al. A phase 1 study of nifurtimox in patients with relapsed/refractory neuroblastoma. J Pediatr Hematol Oncol. 2011; 33(1): 25-30.

Sousa G, Gomes J, Fares R, Damásio MS, Chaves A, Ferreira K, et al. Plasma cytokine expression is associated with cardiac morbidity in Chagas disease. PLoS ONE. 2014; 9(3): e87082.

Vyatkina G, Bhatia V, Gerstner A, Papaconstantinou J, Garg N. Impaired mitochondrial respiratory chain and bioenergetics during chagasic cardiomyopathy development. Biochim Biophys Acta. 2004; 1689(2): 162-73.

WHO - World Health Organization. Chagas disease (American trypanosomiasis). Fact sheet 2017. 2017. Available from: http://www. who.int/mediacentre/factsheets/fs340/en/.

Wong-Baeza C, Nogueda-Torres B, Serna M, Meza-Toledo S, Baeza I, Wong C. Trypanocidal effect of the benzyl ester of N-propyl oxamate: a bi-potential prodrug for the treatment of experimental Chagas disease. BMC Pharmacol Toxicol. 2015; 16: 10. 